Court-Brown, W. M. : Human population cytogenetics. Amsterdam : North-Holland Publ. 1967.

Dutrillaux, B., Finaz, C., Grouchy, J. de, Lejeune, J.: Mise en évidence de la structure fine des chromosomes humains par digestion enzymatique (pronase en particulier). C.R. Acad. Sci. (Paris) 273, 587-589 (1971).

Dutrillaux, B., Lejeune, J.: Etude de la descendance des individus porteurs d'une translocation $t(\mathrm{Dq} \mathrm{Dq})$. Ann. Génét. 13, 11-18 (1970).

Dutrillaux, B., Lejeune, J.: Sur une nouvelle technique d'analyse du caryotype humain. C.R. Acad. Sci. (Paris) 272, 2638-2641 (1971).

Finaz, C., Grouchy, J. de: Le caryotype humain après traitement par l'achymotrypsine. Ann. Génét. 14, 309-311 (1971).

Grouchy, J. de, Roubin, M., Passage, E.: Microtechnique pour l'étude des chromosomes humains à partir d'une culture de leucocytes sanguins. Ann. Génét. 7, 45-49 (1964).

Hecht, F., Kimberling, W. J.: Patterns of D chromosome involvement in human (Dq Dq and Dq Gq) Robertsonian rearrangements. Amer. J. hum. Genet. 19, $399-415$ (1967).

Schnedl, W.: Analysis of the human karyotype using a reassociation technique. Chromosoma (Berl.) 34, 448-454 (1971).

Seabright, M.: The use of proteolytic enzymes for the mapping of structural rearrangements in the chromosomes of man. Chromosoma (Berl.) 36, 204-210 (1972).

Sumner, A. T., Evans, H. J., Buckland, R. A.: New technique for distinguishing between human chromosomes. Nature (Lond.) New Biol. 232, 31 (1971).

Yunis, J. J., Roldan, L., Yasmineh, W. G., Lee, J. C.: Staining of satellite DNA in metaphase chromosomes. Nature (Lond.) 281, 532 (1971).

Human Population Cytogenetics. Proceedings fifth Pfizer International Symposium, Edinburgh, May 1969.

\author{
C. Stoll \\ Cytogenetics Laboratory \\ Clinique Infantile, CHU \\ F-67000 Strasbourg, France
}

Humangenetik 19, 214 (1973)

(C) by Springer-Verlag 1973

\title{
Erratum
}

\section{Zwei subterminale Heterochromatinregionen bei einer seltenen Form einer 21/21-Translokation}

\author{
M. Bartsch-Sandhoff und H. Schade \\ Humangenetik 18, 329-336 (1973)
}

Bei der Drucklegung des Karyogramms in Abb. 2 war ein Chromosom Nr. 17, bei der Drucklegung des Karyogramms in Abb. 4 ein Chromosom Nr. 19 verlorengegangen.

Professor Dr. H. Schade

Institut für Humangenetik und Anthropologie der Universität

D-4000 Düsseldorf, Ulenbergstraße 127-129

Bundesrepublik Deutschland 